\title{
Role of nano-carbon additives in lead-acid batteries: a review
}

\author{
V MAHAJAN ${ }^{1, *}$, R S BHARJ ${ }^{1}$ and J BHARJ ${ }^{2}$ \\ ${ }^{1}$ Department of Mechanical Engineering, Dr. B.R. Ambedkar National Institute of Technology, Jalandhar, Punjab 144011, \\ India \\ ${ }^{2}$ Department of Applied Physics, Dr. B.R. Ambedkar National Institute of Technology, Jalandhar, Punjab 144011, India \\ *Author for correspondence (vishalm.me.14@nitj.ac.in)
}

MS received 31 July 2017; accepted 19 April 2018; published online 23 January 2019

\begin{abstract}
Development in lead (Pb)-acid batteries (LABs) is an important area of research. The improvement in this electrochemical device is imperative as it can open several new fronts of technological advancement in different sectors like automobile, telecommunications, renewable energy, etc. Since the rapid failure of a $\mathrm{LAB}$ due to $\mathrm{Pb}$ sulphation under partial-state-of-charging, electrode grid corrosion and water loss are some major obstructions in its advancement. The doping of various carbon forms into the negative active material of an electrode has been suggested to be effective at improving the storage capacity and cyclic life of LABs by suppressing irreversible sulphation. This report is an attempt to focus on different theories related to the working mechanism of carbon and to summarize the investigation results observed by various researchers regarding the significant role of nano-carbon additives in LABs. On the basis of that, we tried to compare their performance along with the discussion on the best possible additive.
\end{abstract}

Keywords. Lead-acid battery; sulphation; $\mathrm{PbSO}_{4}$ crystals; negative active material; HRPSoC testing; nano-carbon additives.

\section{Introduction}

Since 1859, when Gaston Planté invented a rechargeable lead $(\mathrm{Pb})$-acid battery $(\mathrm{LAB})$, this significant secondary source of power has come a long way with its wide range of applications in the present era. Due to its relatively low cost and recyclability, it was able to capture $60 \%$ share of $\$ 54$ billion global battery market in 2013 [1]. Currently, its large-scale utilization in the automotive sector for starting, lighting and ignition (SLI) purpose, in household inverter power systems and in solar as well as wind-energy storage applications confirms its reliability factor. Particularly, for SLI applications, maintenance-free batteries are in tremendous demand and this appears to grow more in future as the global industry is emerging at the rate of $4 \%$ per year [2]. But, existing $\mathrm{LAB}$ technology is required to overcome its limitations (like sulphation, problem of acid stratification, shedding of active material etc.) and come up with more potential to fulfil the demand of the automotive industry for hybrid-vehicle applications $[3,4]$. In this regard, a LAB is competing with Li-ion battery technology to sustain as the battery of future. But favourably, LABs have the advantages of their low initial cost and well-established recycling systems, whereas the recycling of Li-ion batteries is difficult [5] and still at the laboratory scale. The continuous research and development in the $\mathrm{LAB}$ sector with the focus on carbon as an ingredient in its negative-/positive-electrode active material has played a substantial role in battery life enhancement while operating under high-rate partial-state-of-charge (HRPSoC) conditions along with improvement in the charge/discharge process.

Recently, the effects of various carbon forms on LAB performance under partial state of charging situation have been studied extensively by many researchers and reported it as a significant additive mainly in negative electrodes against sulphation problem [6-18]. Regarding this, carbons of different particle sizes ranging from micrometre- to nanometre-level have been considered for testing. Therefore, this report reviews about different theories associated with the working mechanism of carbon and the beneficial effects of nano-scale carbon additives related to LABs.

\section{Redox phases of LAB electrodes}

In LABs, the curing process of both negative and positive electrodes generates tri-basic $\mathrm{Pb}$ sulphate (3BS, orthorhombic) and tetra-basic $\mathrm{Pb}$ sulphate (4BS, tetragonal) crystals in higher proportion along with some percentages of $\mathrm{Pb}$ oxides and free $\mathrm{Pb}$. The greater presence of 4BS indicates the good stability of positive active mass (PAM) which leads to the longer cyclic lifespan of a cell $[19,20]$. During the very first charging (called as formation process), a two-stage reduction occurs for a negative-electrode material. Initially, it gets converted into spongy $\mathrm{Pb}$ forming a skeleton-type structure as shown in figure 1a which is then followed by dendritic growth of energetic $\mathrm{Pb}$ as a negative active mass (NAM) on 

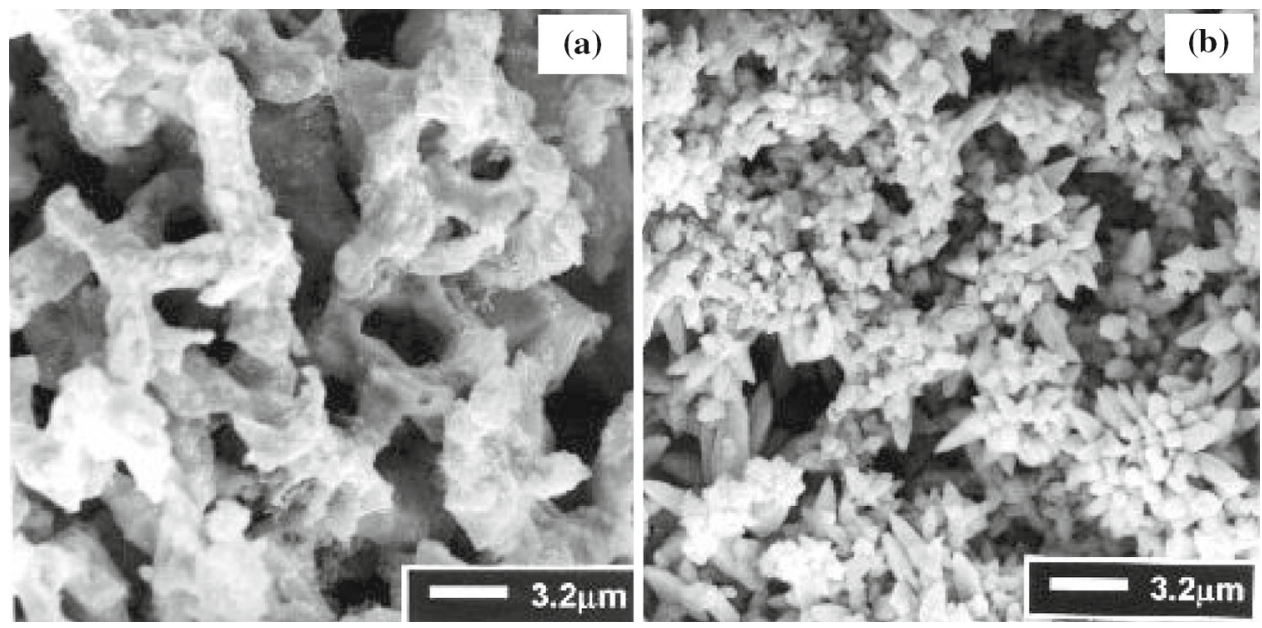

Figure 1. SEM image of (a) primary skeleton type structure of NAM formation and (b) dendritic growth of soft $\mathrm{Pb}$ particles on the primary structure. Reprinted from ref. [22]. Copyright 1981, with permission from Elsevier.

that structure, figure $1 b$. At the same time, the oxidation of positive plate material produces $\alpha-\mathrm{PbO}_{2}$ as a base skeleton structure and $\beta-\mathrm{PbO}_{2}$ as an energetic PAM on that $[19,21]$.

In a battery, an electrolyte usually comprised of $32 \%$ $\mathrm{H}_{2} \mathrm{SO}_{4}+68 \% \mathrm{H}_{2} \mathrm{O} ; \mathrm{H}_{2} \mathrm{SO}_{4}$ in the presence of $\mathrm{H}_{2} \mathrm{O}$ molecules remains in the dissociated state as shown in equation (1). On the application of load, the LAB undergoes a discharge process in which NAM gets oxidized (releases electrons) leading to the formation of an amorphous orthorhombic phase of lead sulphate $\left(\mathrm{PbSO}_{4}\right)$ (equation (2)). While on the positive electrode, $\mathrm{PbO}_{2}$ gains the electrons and in the presence of an electrolyte converts to $\mathrm{PbSO}_{4}$ and water molecules (equation (3)). Whereas during charging, the reverse of these electrochemical reactions takes place, which leads to dissolution of the so-formed $\mathrm{PbSO}_{4}$ crystals on both negative and positive electrodes and their reduction back to $\mathrm{Pb}$ and $\mathrm{PbO}_{2}$ phases, respectively.

$$
\mathrm{H}_{2} \mathrm{SO}_{4} \rightleftharpoons \mathrm{H}^{+}+\mathrm{SO}_{4}^{-} \text {. }
$$

At the negative electrode:

$$
\begin{aligned}
& \mathrm{Pb}+\mathrm{HSO}_{4}^{-} \underset{\text { Charging, Reduction }}{\stackrel{\text { Discharging, Oxidation }}{\rightleftharpoons}} \underbrace{\mathrm{PbSO}_{4}}_{\text {Amorphous structure }} \\
& +2 \mathrm{e}^{-}+\mathrm{H}^{+} .
\end{aligned}
$$

At the positive electrode:

$$
\begin{gathered}
\mathrm{PbO}_{2}+\underbrace{\mathrm{HSO}_{4}^{-}+3 \mathrm{H}^{+}}+2 \mathrm{e}^{-} \stackrel{\text { Discharging, Reduction }}{\rightleftharpoons} \\
\mathrm{PbSarging}_{4} \text { Oxidation } \\
+2 \mathrm{H}_{2} \mathrm{O} .
\end{gathered}
$$

Amorphous structure
But under HRPSoC conditions, where a LAB delivers high-discharge current and gets a short duration of charge only, these reverse electrochemical reactions usually get hindered [23-27] mainly due to

(i) Recrystallization of amorphous $\mathrm{PbSO}_{4}$ particles generated during the discharge process into rigid crystalline form (usually large in size $>10 \mu \mathrm{m}$ [28]) which are hard to be reduced because of its low specific surface area (SSA) or porosity [7].

(ii) The non-conducting nature of the so-formed $\mathrm{PbSO}_{4}$ crystals hinders the reaction process $[8,9,18,29]$.

Therefore, this irreversibility causes the permanent deposition of the hard crystalline phase of $\mathrm{PbSO}_{4}$ as an inactive material on electrodes $[19,25]$ as shown schematically in figure 2. This is generally termed as 'irreversible sulphation' which keeps on increasing with operating cycles and is a major cause of LAB failure $[30,31]$. Further, the rise in working temperature [32] and high depth of discharge (DOD) [33-38] are some other factors which can accelerate it. This sulphation is more pronounced in negative electrodes [39,40] which limits the performance of LABs in terms of:

- low capacity storage due to no longer participation of inactive $\mathrm{PbSO}_{4}$ in charge storage.

- Slow charging rate due to increase in internal resistance.

- Poor cycling performance.

\section{Functioning of carbon against sulphation}

To date, for the advancement in the LAB field, different forms of carbon like graphitic carbon, activated carbon, carbon black 


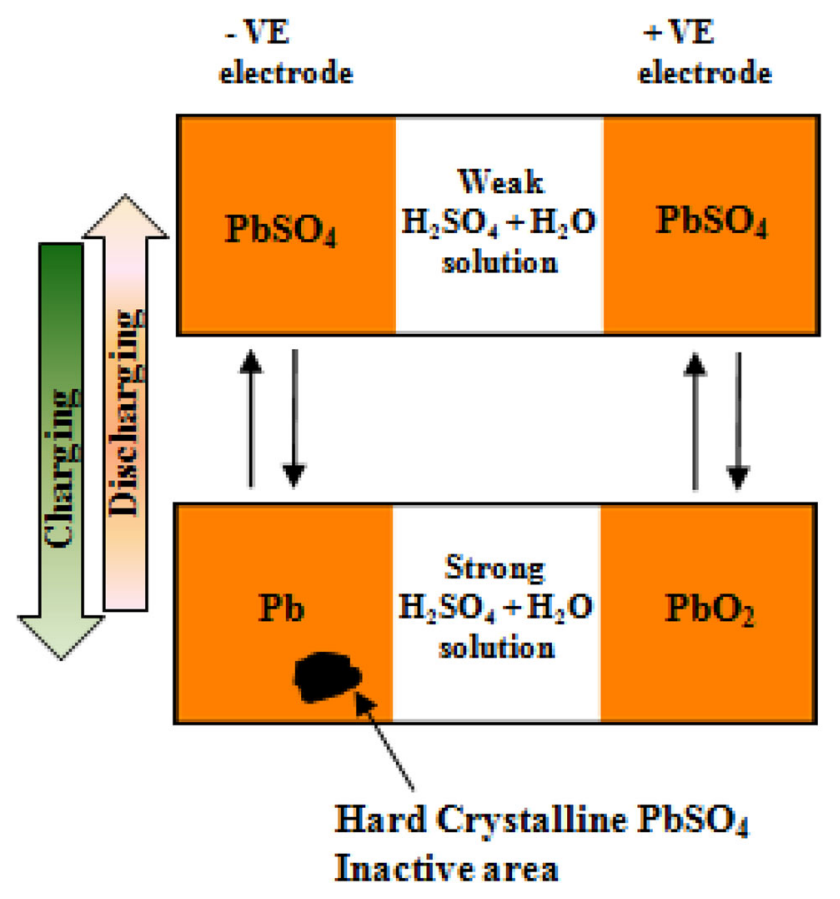

Figure 2. Schematic of the LAB charge-discharge process. Irreversible sulphation in negative electrodes is shown as black portion.

(CB) and a variety of other carbon fibres have been tested separately or in the form of blend with each other [6-18,41, 42]. Regarding their useful roles in LAB performance, four different possible functions of carbon as suggested by various authors have been summarized as follows:

\subsection{Carbon electrical conductivity}

Under the condition of PSoC, the uncharged mass of negative electrodes (present in the amorphous $\mathrm{PbSO}_{4}$ form) slowly gets converted into the hard crystalline form (irreversible $\mathrm{PbSO}_{4}$ ), which tends to enlarge in size with the passage of cycling $[19,43]$. Such passive non-conducting and nonporous $\mathrm{PbSO}_{4}$ particles preferably get deposit and grow on the outer interface of the electrode and in this way develop an insulating barrier which increases the ohmic resistance of the active material. Therefore, a restriction in charge flow and electrolyte movement results in a slowdown of the electrochemical process [12]. But, the inclusion of carbon is supposed to provide a conductive support to charge travel at the carbon/electrolyte interface acting as a pathway of electron access through the non-conductive sulphation barrier leading to successful completion of electrochemical reactions $[44,45]$. A schematic of a useful network of carbon particles in a negative-electrode material providing conductive paths is shown in figure $3 \mathrm{a}$.

The level of electrical conductivity of carbon is largely decided by the amount of $\mathrm{sp}^{2}$ hybridization or graphitization (as graphite is $\mathrm{sp}^{2}$ hybridized and a good conductor) [46].
In the case of low conductive carbon, many researchers tried with graphite mixing to develop a conductive carbon additive $[12,14,47]$. A significant decrease in resistivity of the $\mathrm{PbSO}_{4}$ insulate matrix was noticed with addition of a poorly conductive nanometric form of CB [9]. It was likely due to an electron tunnelling effect induced at such low (nano)dimensions in the presence of high particle density. In comparison with this, activated carbon of micrometre dimensions (conductivity $>\mathrm{CB}$ ) was unable to do so. Therefore, regarding this conductive role of the carbon additive, it can be presumed that even the low conductive carbons having particles in nanorange are able to play a significant role in facilitating the electron mobility on the surface as well as in the core of active mass. On the other hand, highly conductive nano-forms of carbon (multi-walled or single-walled carbon nanotubes (MWCNTs/SWCNTs), graphene etc.) with high SSA have been proven as the best performing additives of carbon to date providing outstanding improvement in the LAB performance parameters (cyclic life, specific capacitance, discharge current, etc.) [48-52].

\subsection{Restriction in crystal growth}

According to this mechanism, carbon inclusion restricts the large size unrestrained growth of $\mathrm{PbSO}_{4}$ particles/crystals. In this regard, the carbon particles by occupying some of the pore volume (relatively of large size pores) reduce the average size of pores of the NAM structure and thus limit the space around $\mathrm{PbSO}_{4}$ crystals to grow as shown schematically in figure $3 \mathrm{~b}$. In this way, a sort of physical constraint is introduced $[41,44,53]$. Such small size crystals have been suggested to be suitable for the long-life of LABs working under HRPSoC cycling conditions as high-surface area of these porous crystals increases their tendency to take part in reversible reaction and release of $\mathrm{Pb}^{2+}$ ions by their easy dissolution in the electrolyte during charging [54]. This theory was also supported by an experiment [55] where a non-conducting, non-carbonaceous additive, $\mathrm{TiO}_{2}$ of size 1-3 $\mu \mathrm{m}$, was introduced into the negative-electrode material and shown equally effective at hindering the size of $\mathrm{PbSO}_{4}$ crystals similar to graphite (a conductive additive of the same size).

\subsection{Capacitive action}

In this mechanism, carbon in good contact with the primary $\mathrm{Pb}$ surface is considered to be acting like a double-layer capacitor which stores the charge electrostatically during charging (figure $3 \mathrm{c}$ ) and delivers this useful additional charge for high rate discharge requirement (like in automotive batteries) which leads to improvement in HRPSoC charge/discharge performance of a cell $[12,44,45]$. In [12], CB along with graphite of high SSA $\left(24 \mathrm{~m}^{2} \mathrm{~g}^{-1}\right)$ has been found significantly more useful in generating this capacitor effect and increasing the overall charge acceptance power in contrast to graphite of 


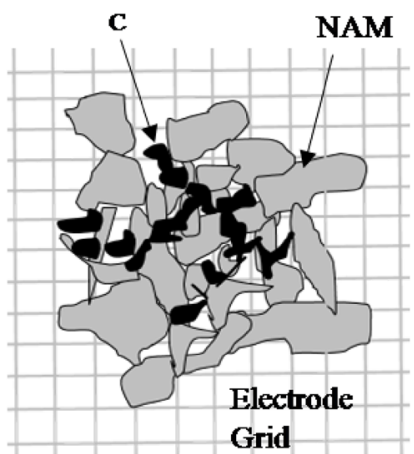

(a)

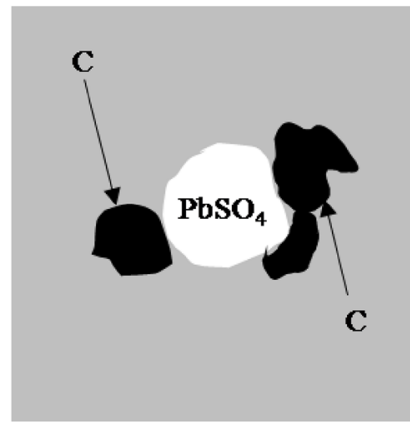

(b)

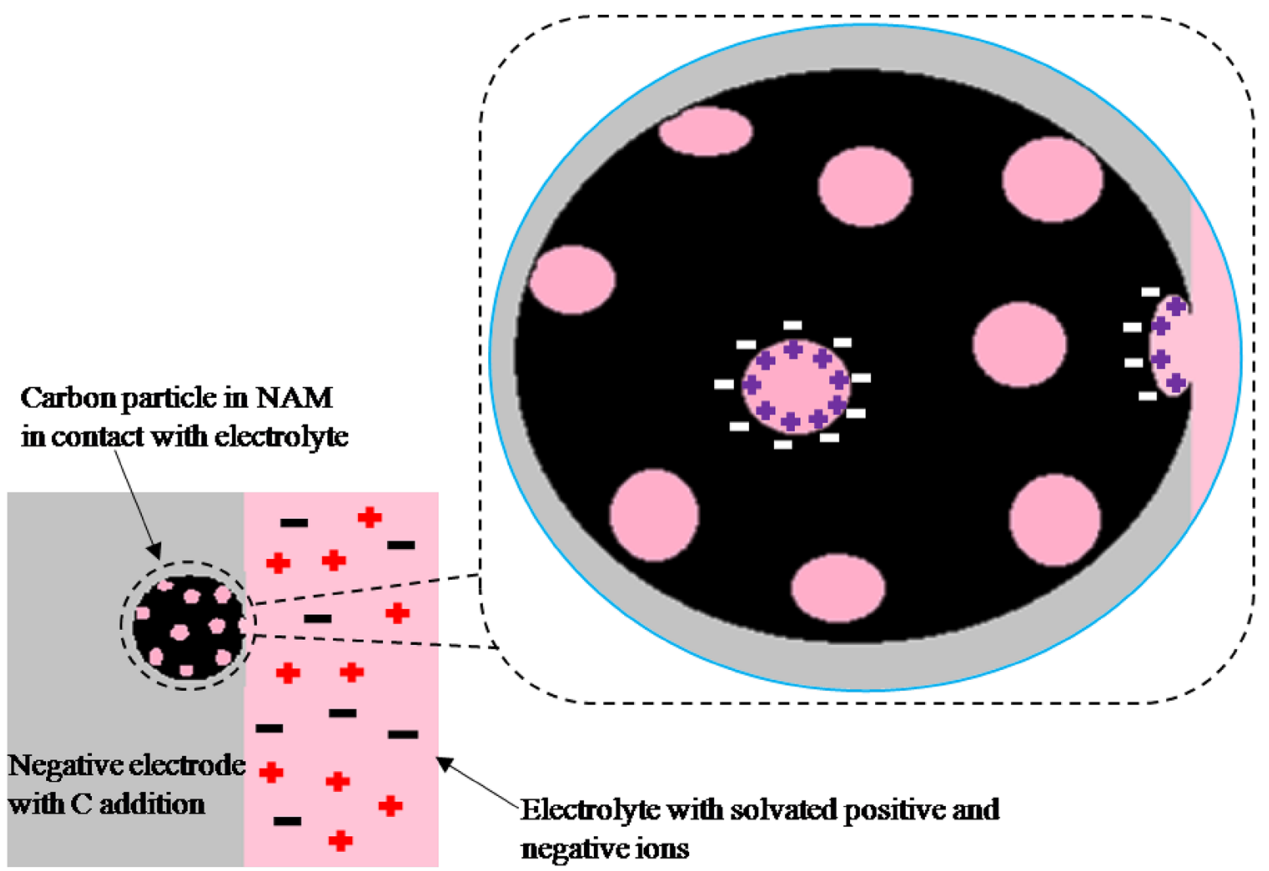

(c)

Figure 3. Schematic of (a) an arrangement of carbon (C) particles in contact with the NAM primary structure and electrode grid suitable for conductivity enhancement. (b) C particles in NAM obstructing the growth of the $\mathrm{PbSO}_{4}$ crystal by physical constraint. (c) Helmholtz double layer of opposite charges on porous $\mathrm{C}$ particles providing capacitive action and holding the additional charge.

low SSA $\left(9 \mathrm{~m}^{2} \mathrm{~g}^{-1}\right)$. It has been emphasized that in a NAM, this non-faradaic charge absorption/desorption process at the $\mathrm{Pb} /$ carbon interface goes side by side with regular faradaic electrochemical reaction at the $\mathrm{Pb} / \mathrm{PbSO}_{4}$ surface $[47,56]$. Surprisingly, the process rate of latter one when estimated was just 1/10th in comparison with former one [54]. Moreover, it has been observed that the high SSA of carbon merely is not that much beneficial in increasing the charge capacitance value unless the electrical conductivity of that particular additive is not high. Therefore, for enhancement in charge capacity, both factors were shown complementing each other and providing superior results together [57]. So accordingly, nano-carbons usually having a large surface area can improve the LAB performance under HRPSoC by inducing such capacitive action.

\subsection{Electrocatalytic effect}

According to this, in a NAM, the adsorbed carbon on the $\mathrm{Pb}$ surface exhibits a catalytic action and accelerates the electrochemical reduction of $\mathrm{Pb}^{2+}$ to $\mathrm{Pb}$ by providing easy access of electrons on its surface (carbon $+\mathrm{Pb}$ ) in comparison with the $\mathrm{Pb}$ surface as shown in figure 4. This electrocatalytic effect was demonstrated experimentally using electrochemically active carbons (EACs) and concluded to vary from carbon to carbon [41]. Therefore, this provision of the alternative low resistive path by carbon, resulting in a two-way reduction process (both on carbon and $\mathrm{Pb}$ ) could be one of the possible mechanisms behind the improvement of electrochemical performance of LAB cells working under partial charging conditions. 


\section{Role of nano-carbon additives}

Starting from the work of Pavlov et al (2009) where the effect of four different EACs, out of which three were of nanoparticle size and one in the micrometre range (table 1), was reported [41]. For the same particle size of $30 \mathrm{~nm}$, considering EAC2 and EAC4, the EAC4 with high SSA was able to enhance the overall active surface area of the NAM structure to close to $4 \mathrm{~m}^{2} \mathrm{~g}^{-1}$ (mentioned finest value) even at low $0.5 \mathrm{wt} \%$ addition. And there was an increase in the cycle life of LAB cells under HRPSoC testing conditions (figure 5). Moreover, in their further research [58], which showcased the comparison with micrometre size particles, the nano-carbon additives were found to perform poorly due to the restricted access of an electrolyte attributed to the reduction of the NAM pore radius (below $1.5 \mu \mathrm{m}$ ).

By comparison of two different types of carbon additives, Printex carbons and active carbons [54], it was shown that the presence of Vanisperse-A (an essential expander component in the NAM) completely suppresses the positive impact of above two nano-range additives by getting adsorbed on their porous surface. But in the absence of Vanisperse-A, the active carbons were examined to be more suitable for enhancement in charge acceptance and HRPSoC cycling life of LAB attributed to their high capacitive action because of high SSA.
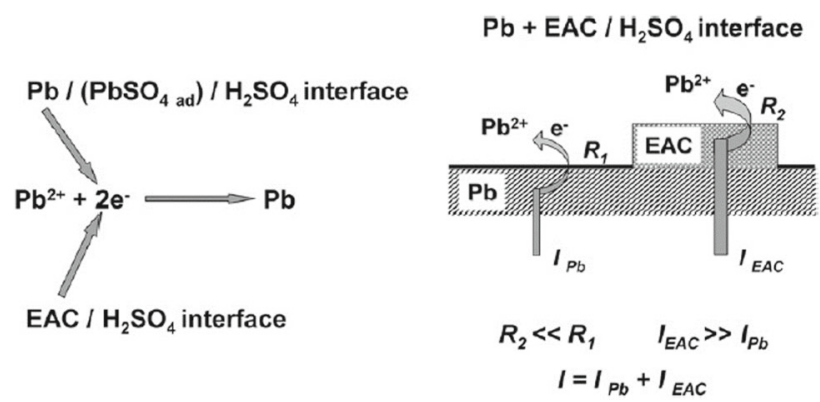

Figure 4. Schematic representation of the electrocatalytic effect of carbon, showing parallel reduction of $\mathrm{Pb}^{2+}$ to $\mathrm{Pb}$ on both carbon and $\mathrm{Pb}$ surfaces. Reprinted from ref. [41]. Copyright 2009, with permission from Elsevier.
In another study, to improve the charge-discharge ability of LABs for utilization in hybrid vehicles, a conductive CB having a particle size of $27 \mathrm{~nm}$ and SSA of $80 \mathrm{~m}^{2} \mathrm{~g}^{-1}$ in combination with expanded graphite (EG-1) of size $10 \mu \mathrm{m}$ and SSA of $24 \mathrm{~m}^{2} \mathrm{~g}^{-1}$ was tested in a NAM of $6 \mathrm{~V}, 24 \mathrm{Ah}$ VRLA battery modules [12]. Following HRPSoC testing situations, the addition of nano-dimensional CB showed 30-60\% surge in charge acceptance (especially at low SoC \%) in comparison with a merely EG-1 carrying module.

In 2011, Sandia report [14] highlighted the advantageous effect of addition of acetylene black (AB) and conductive $\mathrm{CB}$, both having particle size of $20-30 \mathrm{~nm}$ and SSA of $70-80 \mathrm{~m}^{2} \mathrm{~g}^{-1}$, useful in limiting the hard sulphation growth in reference to activated carbon of size $>20 \mu \mathrm{m}$ and SSA $>2000 \mathrm{~m}^{2} \mathrm{~g}^{-1}$. Also, through the SEM images, it was presented that the above two carbon nano-forms resulted in slow and small size distributed growth of $\mathrm{PbSO}_{4}$ crystals during discharge in place of usually concentrated growth on the outer interface of the electrode (figure 6).

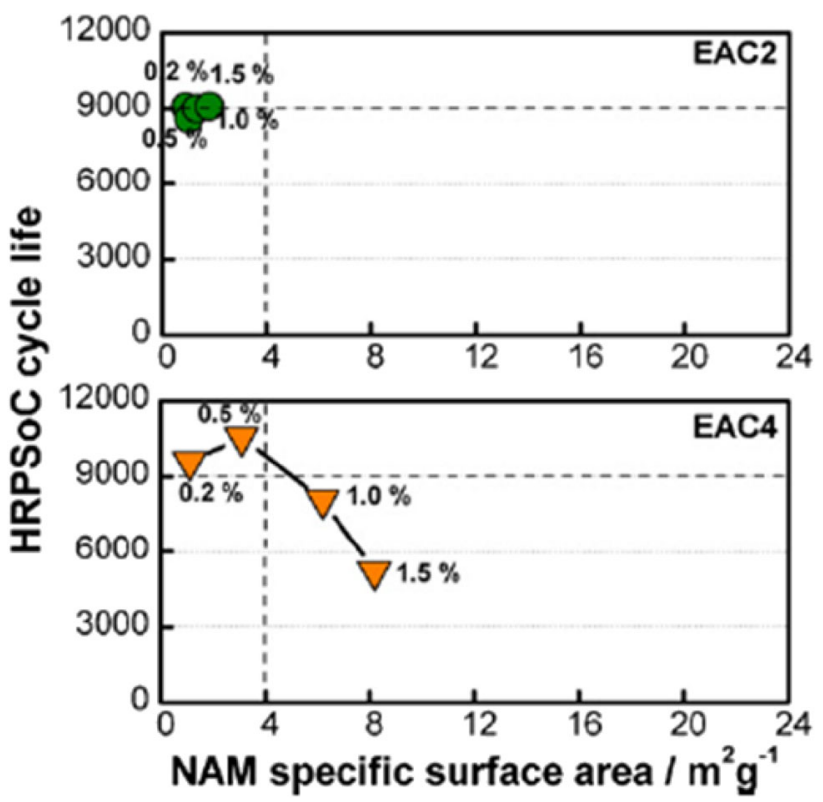

Figure 5. Variation in the HRPSoC cycle life of 4.5 Ah LAB cells regarding the NAM specific surface area changing with addition of EAC2 and EAC4. Reprinted from ref. [41]. Copyright 2009, with permission from Elsevier.

Table 1. Different carbon additives investigated by Pavlov et al. Reproduced from ref. [41]. Copyright 2009, with permission from Elsevier.

\begin{tabular}{lccccc}
\hline \multirow{2}{*}{ Product } & Manufacturer & Type of material & Signature & Particle size $(\mu \mathrm{m})$ & ${\mathrm{BET} \mathrm{surface}\left(\mathrm{m}^{2} \mathrm{~g}^{-1}\right)}^{$\cline { 3 - 4 }$}$ \\
\hline NORIT AZO & NORIT & Activated carbon & EAC1 & 100 & 635 \\
VULCAN XC72R & Cabot Corporation & CB & EAC2 & 30 & 257 \\
Black Pearls 2000 & Cabot Corporation & CB & EAC3 & 12 & 1475 \\
PRINTEX XE2 & Degussa & CB & EAC4 & 30 & 910 \\
\hline
\end{tabular}



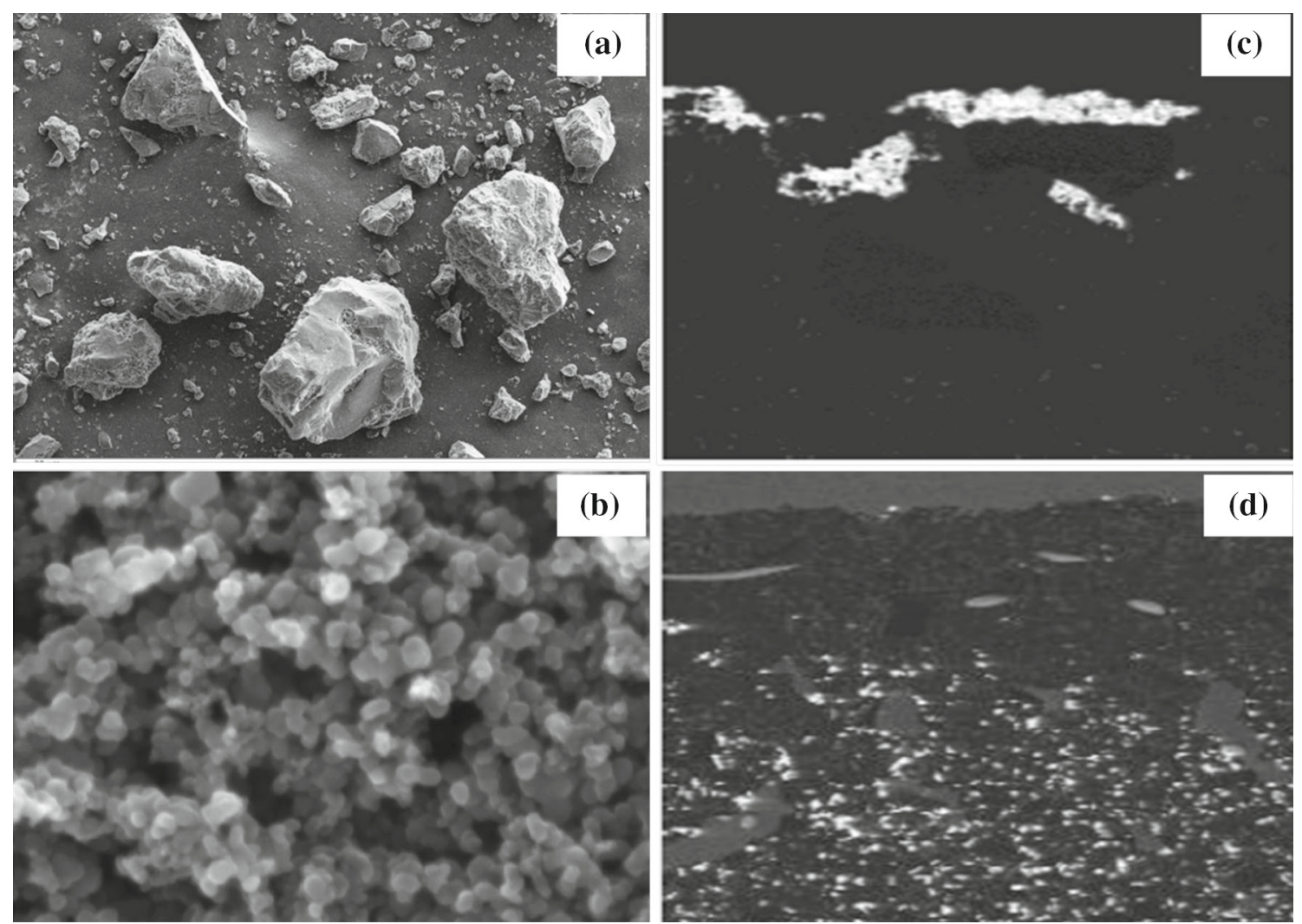

Figure 6. SEM images of (a) activated carbon and (b) CB additives. Cathodoluminescence image of a negative plate having (c) activated carbon displaying hard sulphation (in white) as a concentrated growth on the plate surface, whereas (d) in conductive $\mathrm{CB}$, small and evenly distributed $\mathrm{PbSO}_{4}$ crystals are present, measured after 10,000 HRPSoC cycles. Field of view of (c) and (d) are 264 and $633 \mu \mathrm{m}$, respectively [14].

Moreover, in a report [57], the non-faradaic charge contribution of various combinations of different carbon forms was examined by using the cyclic voltammetry (CV) technique (figure 7). For almost the same SSA, 96.9 and $108 \mathrm{~m}^{2} \mathrm{~g}^{-1}$ of $\mathrm{CB}$ and $\mathrm{AB}$ (of particle size, 13 and $15 \mathrm{~nm}$ ), respectively, it was shown that high SSA value is significantly more helpful in increasing the charge capacitance of active material only if the electrical conductivity of that particular additive material is also good but describing the former one as the main contributing factor.

Further in a research [18], apart from conventional carbon forms, the role of MWCNTs in LABs was explored with a considerable rise in the cycle life of a $2 \mathrm{~V}, 2 \mathrm{Ah}$ LAB cell, tested at the 10-h rate, under HRPSoC conditions. The credit was given to high SSA of this carbon nanostructured material and its established conductive network within the NAM. Moreover, an increase in cell capacity value with stability and reduction in required charging potential was noticed when compared with conventional CB additive (figure 8). Similarly, a study was exercised with MWCNTs and graphene (a two-dimensional (2D) allotrope of carbon) in LAB's NAM on individual basis [51]. With their addition, an almost two times increase in overall porosity of negative electrodes was observed relative to $17 \%$ (without any additive) attributed to

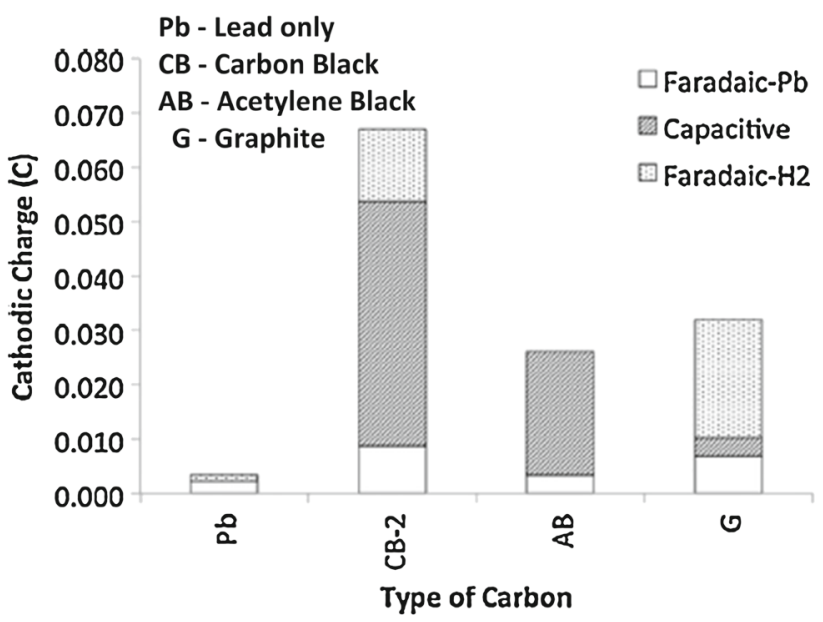

Figure 7. CV data analysis shows more contribution to capacitive charge by CB2 having three times less resistance compared with AB $\left(14.9 \Omega \mathrm{g}^{-1}\right)$. Reprinted from ref. [57]. Copyright 2015, with permission from Elsevier.

small size growth of $\mathrm{PbSO}_{4}$ crystals with uniformity. Such an increase in overall pore volume was said to be useful for easy diffusion of an electrolyte within active material. A fine 

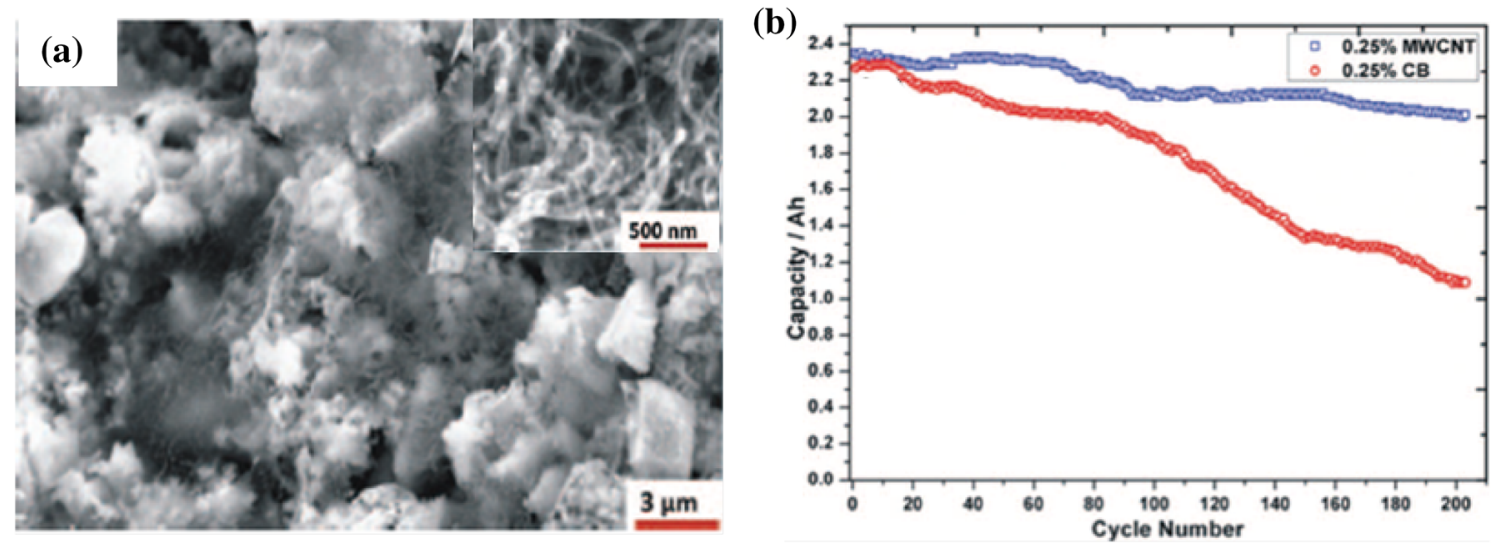

Figure 8. (a) SEM image revealing a conductive network formation by MWCNTs in the NAM. The inset displays the pristine MWCNTs. (b) Increase in cell capacity with addition of MWCNTs compared with conventional CB. Reprinted with permission from ref. [18]. Copyright 2013, The Electrochemical Society.

integration of these nanostructured materials within the primary $\mathrm{Pb}$ skeleton structure of NAM was observed and concluded effective for active material utilization and enhancement of charge/discharge performance of LABs. Considering another study [59] in which CV examination was carried out, an increase in current density ( 475 to $675 \mathrm{~mA} \mathrm{~cm}^{-2}$ ) and specific capacitance ( 850 to $1250 \mu \mathrm{F} \mathrm{cm}^{-2}$ ) of the main test electrode made of carbon foam (heat treated up to $1400^{\circ} \mathrm{C}$ ) was reported, mainly due to addition of MWCNTs (at $1 \mathrm{wt} \%$ ). Furthermore, a better scenario was observed, when a functionalized form of CNTs called as discrete CNTs (dCNTs) with $0.16 \%$ by weight in NAM of $35 \mathrm{Ah}, 12 \mathrm{~V}$ full-scale LAB model was examined under HRPSoC testing [60]. There was more than $200 \%$ increase in current output (at constant voltage discharge). Along with this, LAB performance under cold conditions improved. In further exploration of this [29], the same additive was tested under rigorous Storage Battery Association, Japan, modelled life cycle testing conditions. Interestingly, a 6-fold increase in cycle life was reported when $\mathrm{dCNTs}$ were added into both negative and positive electrodes whereas almost 2-fold increase was reported when added to NAM only. Also, it was depicted through SEM analysis that addition of above nano-dimensional material was helpful in restricting the sulphation growth and keeping the average size of hard $\mathrm{PbSO}_{4}$ particles below $10 \mu \mathrm{m}$, through developing a close arranged, uniform and small size crystal structure in the active material (figure $9 \mathrm{a}-\mathrm{d}$ ).

Similarly, the significant impact of functionalized MWCNTs in both positive and negative electrodes [48] was demonstrated with a low percentage of loading (0.008$0.02 \mathrm{wt} \%$ ). The functionalization (with the $\mathrm{COOH}$ group) was shown effective regarding good dispersion and connectivity of nanotubes with active material. The cycle life of automotive battery cells was almost doubled (at DOD 25\%) comparative with cells with non-functionalized CNTs. It was emphasized that the CNT addition was beneficial for excellent charge conductivity within the NAM and producing small size crystals of discharge product $\left(\mathrm{PbSO}_{4}\right)$ which is supportive for easy reversible conversion/dissolution to $\mathrm{Pb}$.

Also, the potential of graphene as a carbon additive was reported significantly by Yeung et al [52]. Due to the efficient electrical conductive property of graphene, a substantial decrease in ohmic contact resistance was noticed at the NAM/electrolyte interface which likely sourced an improvement in the cycle life of LAB cells (7078 to 17157 cycles) by smoothing the charge transfer for electrochemical reactions. Along with this, negative electrodes containing graphene were also found with approximately $25 \%$ reduced size of $\mathrm{PbSO}_{4}$ irreversible crystals when examined after PSoC failure. A more closeness, as well as uniformity in their formation, was observed as shown in figure $9 \mathrm{e}$ and $\mathrm{f}$.

Moreover, in recent advancement related to LABs [49], a much-improved LAB performance has been observed with SWCNTs. Added to both electrodes, a very low $0.001 \%$ of SWCNTs was shown effective in comparison with $0.05 \%$ of MWCNTs, in achieving the almost same cycle life $(\sim 650$ cycles) in a $2 \mathrm{~V}$ flooded LAB cell [50]. Moreover, tested on a $2 \mathrm{~V}$ gel cell at high-discharge rates, there was a further rise in cycle life with SWCNTs, attributed to their higher conductivity and high volume ratio (figure 10).

Therefore, such improvements in cyclic performance of LABs indicate that the carbon nanostructures with high SSA and low intrinsic resistance are possibly inducing a change in deposition phenomenon of discharge generated $\mathrm{Pb}^{2+}$ ions. They may be promoting the ions to form new nuclei on the large active surface area instead of deposition on already grown $\mathrm{PbSO}_{4}$ particles, resulting in small sized, closed and tight arrangement of the formation of $\mathrm{PbSO}_{4}$ crystals with uniformity. It supports that theory which suggests that an increase in availability of nucleation sites could be one of the possible functions of added carbon [44]. The above idea can further be strengthened by the theory of parallel reduction of $\mathrm{Pb}$ ions on carbon and $\mathrm{Pb}$ particle surfaces, as suggested by Pavlov 

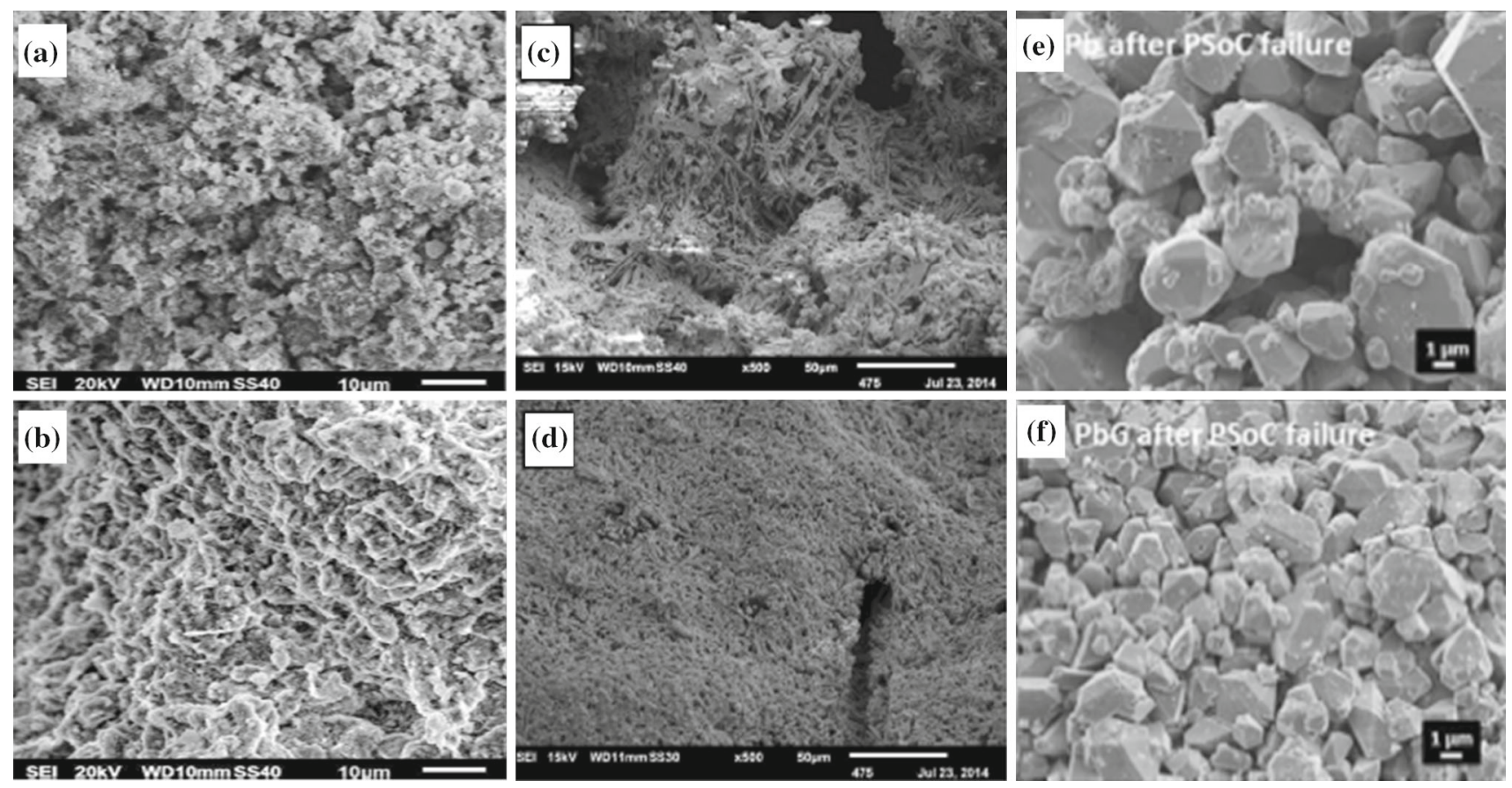

Figure 9. Microscopic view of the NAM of a cured plate (a) without dCNTs and (b) with dCNTs, showing a firm and connected microstructure [60]. Negative plate from a failed battery tested under HRPSoC conditions (c) completed 12,000 cycles without dCNTs and (d) after 19,000 cycles with dCNTs [29]. A negative Pb plate (e) without graphene and (f) with graphene. Panels (e, f) reproduced from ref. [52] with permission from The Royal Society of Chemistry.

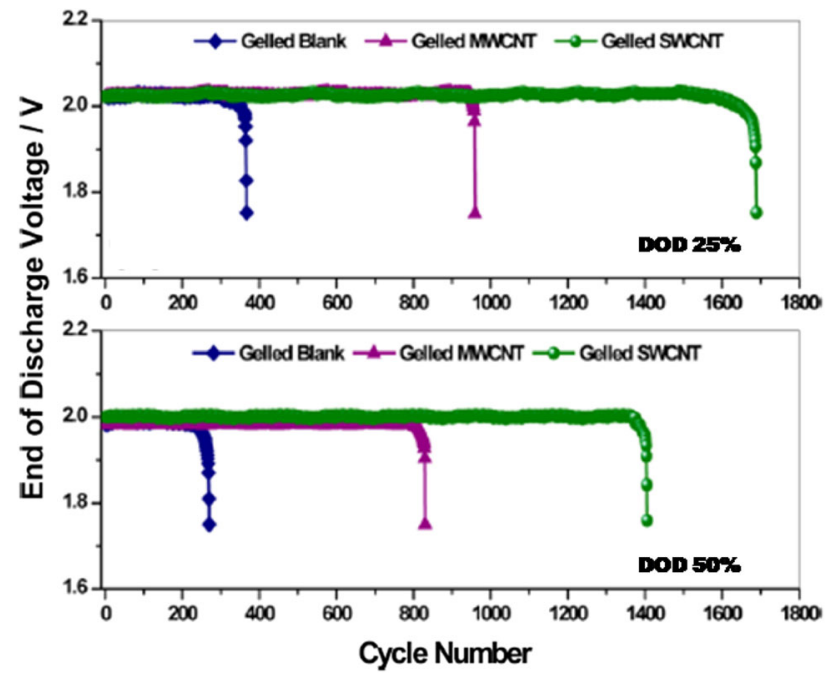

Figure 10. Cyclic performance of $2 \mathrm{~V}$ gel type LAB cells measured at 25 and 50\% DOD, with both electrodes containing SWCNTs or MWCNTs or no CNTs (blank). Reprinted with permission from ref. [50]. Copyright 2017, American Chemical Society.

[41]. In view of that, the inverse of this, the parallel oxidation process should also be true, in which carbon facilitates the oxidation reaction $\left(\mathrm{Pb} \rightarrow \mathrm{Pb}^{2+}+2 \mathrm{e}^{-}\right)$on its high SSA and promotes the deposition of $\mathrm{PbSO}_{4}$ more or less on or adjacent to the carbon, offering new nucleation sites. Therefore, the above consideration may provide an understanding towards the incredible role of carbon nano-additives in suppressing the sulphation rate and enhancing the cyclic life of LABs.

\section{Discussion}

To get the enhanced version of LABs, carbon available in different allotropic forms has been investigated extensively. Figure 11 summarizes the positive and negative attributes of various carbon additives, eventually helpful in making their individual assessment as well as comparative analysis.

Taking into account of all the conventional carbon additives like $\mathrm{CB}, \mathrm{AB}$, activated and graphitic carbons, it can be concluded that whether used separately or in combination with each other, their significant impacts have a great dependency on SSA and electrical conductivity. These two characteristics are considered to play a major role in driving all the potential working mechanisms related to carbon addition which can further be enhanced by appropriate mixing of different characteristic carbons. Considering the size factor, for the same percentage of addition, there is an advantage of more SSA available with nano-carbon additives relative to micrometre-carbon additives along with better dissemination and inclusion within the active mass. On the contrary, such zero-dimensional (0D) carbon particles are shown liable 


\begin{tabular}{|c|c|c|c|c|c|}
\hline \multirow{2}{*}{$\begin{array}{l}\text { Type of } \\
\text { carbon } \\
\text { additive }\end{array}$} & \multicolumn{3}{|c|}{ Characteristics } & \multirow[b]{2}{*}{ Positive aspocts } & \multirow[b]{2}{*}{ Negative aspocts } \\
\hline & Structure & Specific surface area & $\begin{array}{l}\mathrm{sp}^{2} \text { hybridization } \\
\text { (for electrical } \\
\text { conductance) } \\
\end{array}$ & & \\
\hline $\begin{array}{l}\mathrm{CB}, \mathrm{AB} \\
\text { and } \\
\text { Lamp Black }\end{array}$ & $\begin{array}{l}\text { Spherical shape agglomerates } \\
\text { of small porous particles } \\
\text { (produced by incomplete } \\
\text { combustion or thermal } \\
\text { decomposition of liquid or } \\
\text { gaseous hydro-carbons. }\end{array}$ & $\begin{array}{l}70-80 \mathrm{~m}^{2} \mathrm{~g}^{1} \text { for } \\
20-30 \mathrm{~nm} \text { particle } \\
\text { size [14], } \\
300 \mathrm{~m}^{2} \mathrm{~g}^{-1} \text { for } 14 \mathrm{~nm} \\
\text { particle size, Printex } \\
\text { CB [54] }\end{array}$ & $\begin{array}{l}\text { Partially } \text { sp }^{2} \\
\text { hybridized } \\
\text { (Low conductivity) }\end{array}$ & \multirow{2}{*}{$\begin{array}{l}\text { - Inhibit the hard sulphation [12-14]. } \\
\text { Restrict the large size growth of the } \mathrm{PbSO}_{4} \text { crystals by filling large } \\
\text { pores in NAM [41,54]. } \\
\text { Due to their porous nature, act as supplier of electrolytic ions }\left(\mathrm{H}^{+} \text {and }\right. \\
\left.\text { HSO } \mathrm{O}_{4}\right) \text { to inner of the plate [47,61]. } \\
\text { Enhance the overall porosity as well as active surface area of NAM } \\
\text { [12]. } \\
\text { Provide electro-catalytic effect [41]. } \\
\text { For better outcomes, they can be mixed with some form of graphitic } \\
\text { carbon for conductivity improvement [12,47,57]. } \\
\text { - Activated carbons exhibit high capacitive action as well as electro- } \\
\text { catalytic effect due to availability of more SSA in omparison to CB for } \\
\text { the same size and percentage of loading [54]. }\end{array}$} & \multirow{2}{*}{$\begin{array}{l}\text { - Ineffective in presence of Vanisperse }-\mathrm{A}[54] \text {. } \\
\text { Nano-size can obstruct the flow of electrolyte by } \\
\text { generating NAM structure with pore size }<1.5 \mu \mathrm{m} \\
{[41,58] \text {. }} \\
\text { An optimum percentage of addition is required which } \\
\text { varies from carbon to carbon [41]- } \\
\text { Weak integration with the active material }[13,54] \text {. } \\
\text { Not suitable for positive electrode because of its } \\
\text { possibility to get oxidized to } \mathrm{CO}_{2}[29,62] \text {. } \\
\text { Problem of hydrogen cvolution, resalting in electrolytc } \\
\text { loss [58,63,64]. } \\
\text { High SSA of carbon can cause self discharge of battery } \\
\text { [14,65]. }\end{array}$} \\
\hline $\begin{array}{l}\text { Activated } \\
\text { Carbons }\end{array}$ & $\begin{array}{l}\text { Spherical shape agglomerates } \\
\text { (of CB, AB etc.) subjected to } \\
\text { additional activation treatment } \\
\text { for more porosity } \\
\text { Or } \\
\text { A powder with irregular shape } \\
\text { particles equipped with high } \\
\text { number of low volume pores } \\
\text { derived from charcoal, coal or } \\
\text { cole. }\end{array}$ & $\begin{array}{l}1156 \mathrm{~m}^{2} \mathrm{~g}^{-1} \text { for } 4 \mu \mathrm{m} \\
\text { particle size }[47] \\
2000 \mathrm{~m}^{2} \mathrm{~g}^{-1} \text { for }>20 \\
\mu \mathrm{m} \text { particle size }[14]\end{array}$ & $\begin{array}{l}\text { Partially } \mathrm{sp}^{2} \\
\text { hybridized } \\
\text { (Low conductivity) }\end{array}$ & & \\
\hline $\begin{array}{l}\text { Graphitic } \\
\text { Carbons }\end{array}$ & $\begin{array}{l}\text { A laycred structure, consists of } \\
\mathrm{sp}^{2} \text { hybridized carbon } \\
\text { hexagonal sheets. }\end{array}$ & $\begin{array}{l}24 \mathrm{~m}^{2} \mathrm{~g}^{-1} \text { for } 10 \mu \mathrm{m} \\
\text { particle size [12] } \\
7.4 \mathrm{~m}^{2} \mathrm{~g}^{-1} \text { for } 18.5 \\
\mu \mathrm{m} \text { particle size [47] }\end{array}$ & $\begin{array}{l}\text { High degrec of } \mathrm{sp}^{2} \\
\text { hybridization } \\
\text { (good conductivity) } \\
\left(82.33 \mathrm{Scm}^{-1}\right)[47]\end{array}$ & $\begin{array}{l}\text { - Limit the uncontrolled large size growth of } \mathrm{PbSO}_{4} \text { crystals by steric } \\
\text { hindrance [53]. } \\
\text { Provide better results as an additive on mixing with high SSA carbons } \\
{[12,47,57] \text {. }}\end{array}$ & $\begin{array}{l}\text { - Low porosity and SSA in comparison to CB and } \\
\text { activated carbons. } \\
\text { Solely high conductivity of graphite with low active } \\
\text { surface is less significant for improvement }[12,47,57] \text {. }\end{array}$ \\
\hline Graphene & $\begin{array}{l}\text { A single-atom thick layer or } \\
\text { sheet having two dimensional } \\
\text { regular hexagonal arrangement } \\
\text { of sp }^{2} \text { hybridized carbon atoms }\end{array}$ & $\begin{array}{l}2630 \mathrm{~m}^{2} \mathrm{~g}^{-1}[66,67] \\
\text { Thickness of sheet } ~ \\
0.335 \mathrm{~mm}[68]\end{array}$ & $\begin{array}{l}\text { High conductivity } \\
6000 \mathrm{Scm}^{-1}[69,70]\end{array}$ & $\begin{array}{ll} & \text { Reduce sulphation [51,52]- } \\
\text { Raise overall porosity of NAM structure (nearly two-fold rise) [51]- } \\
\text { Increase electrochemical surface area of NAM at small percentage } \\
\text { addition (0.33\%) [51]. } \\
\text { Induce regularity and tightness in NAM through small size ( }<10 \\
\text { micron) growth of lead sulphate [51]. } \\
\text { Facilitate the charge transfer phenomenon [52]. }\end{array}$ & $\begin{array}{l}\text { - For the same amount of loading }(0.33 \mathrm{wt} \% \text {, an increase } \\
\text { in specific capacity of active material was less in } \\
\text { comparison to MWCNTs [51]. } \\
\text { - High cost of production. }\end{array}$ \\
\hline swCNTs & $\begin{array}{l}\text { One dimensional nanomaterial } \\
\text { with tube like structure similar } \\
\text { to the rolled form of single } \\
\text { Graphene sheet }\end{array}$ & $\begin{array}{l}>1600 \mathrm{~m}^{2} \mathrm{~g}^{-1} \\
{[71,72]} \\
\text { Dia. } 0.4 \text { to } 2-3 \mathrm{~nm} \\
\text { and length in few } \\
\mu \mathrm{m}[73]\end{array}$ & $\begin{array}{l}\mathrm{sp}^{2} \text { hybridized carbon } \\
\text { atoms } \\
\text { High conductivity } \\
\sim 5000 \mathrm{~S} \mathrm{~cm}^{-1}[74-77]\end{array}$ & $\begin{array}{ll} & \text { High electrical conductivity. } \\
\text { Increase overall porosity of NAM structure and promote homogeneity } \\
\text { in active mass structure with small size (<10 micron) crystal growth of } \\
\text { PbSO }_{4}[29,51] \text {. } \\
\text { Due to chemical stability, can be used in both electrodes (negative and } \\
\text { positive) for better results [50]. }\end{array}$ & $\begin{array}{l}\text { High production cost. So presently uneconomical for the } \\
\text { largescale use in } L A B \text { industry. } \\
\text { Not a } 100 \% \text { pure form of carbon. Traces of transition- } \\
\text { metal impurities can degrade the performance of LABs } \\
\text { [18]. } \\
\text { Under standard testing conditions, dCNTs (CNTs }\end{array}$ \\
\hline MWCNTs & $\begin{array}{l}\text { Made up of conccntric } \\
\text { arrangement of several } \\
\text { SWCNTs }\end{array}$ & $\begin{array}{l}>430 \mathrm{~m}^{2} \mathrm{~g}^{-1}[71,72] \\
\text { Inner dia. } 0.4 \text { to } 2-3 \\
\mathrm{~nm} \\
\text { Outer dia. } 2 \text { to } 20-50 \\
\mathrm{~nm}[50,73]\end{array}$ & & $\begin{array}{l}\text { - More than } 100 \% \text { improvement in HRPSoC cyclic life on addition to } \\
\text { both eloctrodes [48]. } \\
\text { Due to high length-to-diameter ratio, their small percentage ( } 0.001 \%) \text { in } \\
\text { NAM and PAM is shown significant for longer cyclic life at high depth } \\
\text { of discharge operation [50]. } \\
\text { - Increasecharge acceptance rate [18]. } \\
\text { The functionalization of CNTs can further induce enhancement in } \\
\text { electrochemical performance of LABs [29,48]. }\end{array}$ & $\begin{array}{l}\text { functionalized with - } \mathrm{COOH} \text { group) are shown with an } \\
\text { increase in gas cvolution by } 40-80 \%[29] \text {. }\end{array}$ \\
\hline
\end{tabular}

Figure 11. Various types of carbon with their positive and negative aspects as examined by researchers $[12-14,18,29,41,47,48$, $50-54,57,58,61-77]$.

Tubular structure of CNT
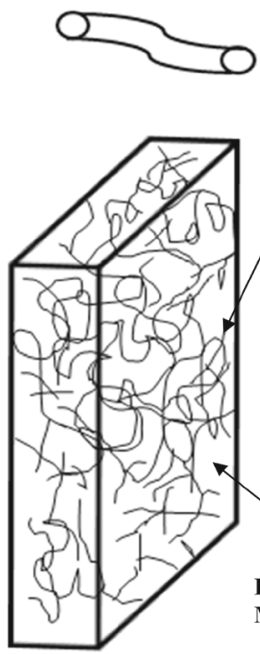

(a)
Plate like structure of Graphene
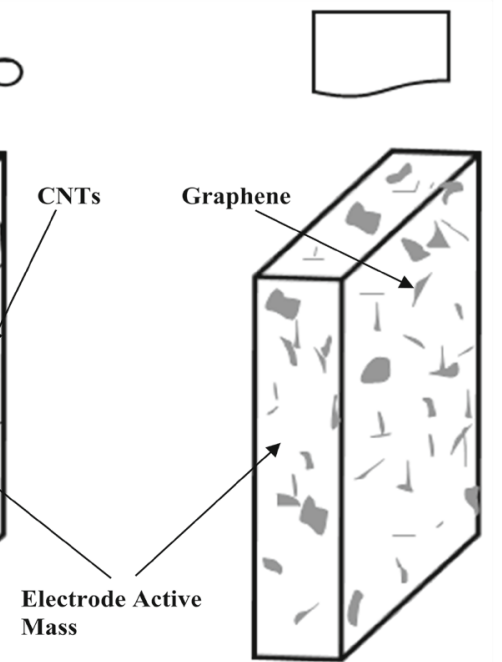

(b)

Figure 12. Schematic showing (a) a continuous $3 \mathrm{D}$ network formation by a CNT-CNT contact within the active mass. (b) Active mass with the lack of graphene-graphene contact system formation.

to bring down the mean pore radius of the NAM structure below $1.5 \mu \mathrm{m}$ (by occupying the space within pores) and obstruct the necessary flow of the electrolyte which leads to undesired $\alpha-\mathrm{PbO}$ formation in a large amount as a reaction product in place of $\mathrm{PbSO}_{4}$, eventually causing low HRPSoC cycle life of LAB cells [41]. Moreover, their unstable integration within the NAM [13] exhibits that in spite of availability of large SSA, the almost spheroid shape of such carbon additives results in scarcity of sites for strong interconnection with the active material which limits their performance. On the other hand, CNTs and graphene were considered as more effective performers in comparison with conventional carbons, especially, in the suppression of hard sulphation of active mass through the evolution of uniform small size particles/crystals of $\mathrm{PbSO}_{4}$ which further smoothens down the reversible charge-discharge process and improves the LAB cycle life [18]. In these well-ordered structures, the two important factors SSA and electrical conductivity are intrinsically very high which plausibly enhance the percentage of benefits coming from each possible working mechanisms associated with carbon addition. By comparing the work of Marom et al [48] and Banerjee et al [50], regarding improvement in the cyclic life of a flooded 
type battery, the effectiveness of these nano-carbon additives can be arranged as SWCNTs $>$ MWCNTs $>$ graphene. SWCNTs being more uniform in structure (fewer defects) $[78,79]$ having the attribute/quality of ballistic conductance [80] are obviously a better performer than MWCNTs. But considering the cost factor, MWCNTs are more economical than SWCNTs [81-83]. Moreover, functionalization of CNTs (with the $-\mathrm{COOH}$ group) induces enhancement in their beneficial effect $[29,48,60]$, likely in the similar order as mentioned above, apparently due to good adhesion and dispersion within the active material. On the other hand, in spite of high SSA and conductivity of graphene, the superior performance of CNTs can be attributed to their tubular morphology (with high-aspect ratio) helpful in developing a significant three-dimensional (3D) conductive network within the NAM matrix, which appears less possible with a plate-like structure of a graphene sheet (figure 12). This can be substantiated by taking into consideration of various reports dealt with the comparative study of CNTs and graphene as fillers in the different polymer matrices for useful electrical percolation. Studies [84-86] show that in comparison with graphene, CNTs are readily efficient in establishing a 3D conductive network within the respective polymer matrix even at a low percolation threshold. And for the same percentage of loading, electrical conductivity of MWCNT-reinforced composites was higher than graphene-based composites. Although it seems inappropriate to correlate the condition of a viscous liquid matrix with a powder matrix, it is necessary to understand the role of configuration factor of these two nano-carbon fillers in their conductive arrangement. Also, a powder matrix can be assumed providing a less resistive environment for such type of 3D system development. Therefore, on the basis of above, an agglomerated but continuous network formation through CNT-CNT contacts within the active mass can be considered providing a most effective conducting system due to its structural configuration as compared with all other carbon additives. It can facilitate the necessary charge supply for easy dissolution of $\mathrm{PbSO}_{4}$ crystals during the charging process. Also, it can be considered useful in providing an essential reinforcement to the active mass. Moreover, the use of CNTs in both the electrodes (anode and cathode) has been reported with more than $100 \%$ improvement in the HRPSoC cycle life test based on the SBA protocol $[29,48]$. The stability of CNTs in the highly oxidizing environment of positive electrodes is another merit which makes it more preferable than other carbon additives.

Considering the negative aspects, high cost of CNTs and problem of outgassing (hydrogen evolution) are important issues. It has been shown [50] that the former one can positively be counterbalanced by incorporating a considerably low proportion of CNTs. In this approach, SWCNTs with merely 0.01 and $0.001 \mathrm{wt} \%$ of loading are shown effective for 3 -fold elongation in the cyclic life of LABs. Along with this, development of low cost and high yielding techniques for CNTs could be an effective solution. In addition, various carbon additives [58,63,87,88] and recently CNTs (functionalized with - $\mathrm{COOH}$ ) [29] have been reported with an undesired surge in outgassing during charging. It can result in electrolyte loss and in long run thermal runaway of valve-regulated LABs $[63,89]$. Studies [90-92] show that doping of carbon with heteroatoms like nitrogen, phosphorous and sulphur (being more electronegative than carbon) is an effective method to inhibit the hydrogen evolution to some extent. Therefore, further research towards understanding the physical and chemical mechanisms driving such gas evolving side reactions can be helpful in their significant suppression. Besides, development of some sort of catalyst-based gas recombination arrangement externally or internally in LABs $[93,94]$ could be helpful to maintain the exact concentration of the electrolyte.

\section{Conclusions}

This paper provides a review of research regarding the substantial role of nano-carbon additives towards improvement in LAB performance. Also, there is mentioning of different mechanisms (suggested by various researchers) through which carbon is possibly enhancing the outcomes of LABs under PSoC working conditions. About these working mechanisms, there is not a single unanimously agreed theory. Moreover, one cannot deny the existence of more than one mechanism behind the beneficial role of carbon. The effect on the performance of LABs varies from carbon to carbon. Its size, SSA and an optimum percentage of addition can change the micro-structural parameters of active material in a useful range. The shedding of active material, grid corrosion and water loss are many causes of LAB failure, but among all, sulphation is the major one. And in this context, present study concludes that various carbon forms are useful but nano-carbons especially SWCNTs have considered as the most effective to date in curbing this problem and extending the battery life through the evolution of uniform small size particles/crystals of $\mathrm{PbSO}_{4}$. Since the cost of production of SWCNTs is extremely high, pristine or functionalized-MWCNTs may be a more suitable futuristic option. However, for the commercial viability of CNT-based LABs, more affordable production techniques for CNTs are required along with a close attention to the problem of hydrogen evolution. Furthermore, attributed to one-dimensional structure, CNTs have more potential to enhance the electrochemical surface area and conductivity of active material even at the low percentage of addition in contrast to $2 \mathrm{D}$ and OD nano-carbon additives. Clearly, nano-dimensionality of carbon has opened a new domain of possibilities in the progressive development of $\mathrm{LABs}$ for future requirement.

\section{Acknowledgements}

The authors thank the Director, National Institute of Technology, Jalandhar (NITJ) for Technical Education 
Quality Improvement Programme (TEQIP-II) support. The authors would also like to thank Mr. Sudipto Ranjan Dass (DGM-R\&D, Luminous Power Technologies, Una (HP), India) for his expertise that significantly assisted this work.

\section{References}

[1] The advanced lead acid battery consortium 2016-2018. Available at: www.alabc.org/publications/overview-of-the-alabc1618-program (accessed on 22 December 2016)

[2] Economic-outlook, the global automotive market, Sept 14 2014. Available at: http://www.eulerhermes.com/mediacenter/ Lists/mediacenter-documents/Economic-Outlook-The-global -Automotive-market-Sept14.pdf (accessed on 02 December 2016)

[3] Budde-Meiwes H, Drillkens J, Lunz B, Muennix J, Rothgang S, Kowal J et al 2013 Proc. Inst. Mech. Eng., Part D 227761

[4] Garche J, Moseley P T and Karden E 2015 In: B Scrosati, J Garche and W Tillmetz (eds) Advances in battery technologies for electric vehicles (Cambridge: Elsevier Ltd) p 75

[5] Xu J, Thomas H R, Francis R W, Lum K R, Wang J and Liang B 2008 J. Power Sources 177512

[6] Endo M, Kim Y A, Hayashi T, Nishimura K, Matusita T, Miyashita K et al 2001 Carbon 391287

[7] Shiomi M, Funato T, Nakamura K, Takahashi K and Tsubota M 1997 J. Power Sources 64147

[8] Ohmae T, Hayashi T and Inoue N 2003 J. Power Sources 116 105

[9] Boden D P, Loosemore D V, Spence M A and Wojcinski T D 2010 J. Power Sources 1954470

[10] Lam L T, Louey R, Haigh N P, Lim O V, Vella D G, Phyland $\mathrm{C}$ G et al 2007 J. Power Sources 17416

[11] Spence M A, Boden D P and Wojcinski T D 2009 ALABC research project designation C1/1/2.1A Progress Report 4

[12] Fernández M, Valenciano J, Trinidad F and Muñoz N $2010 \mathrm{~J}$. Power Sources 1954458

[13] Ebner E, Burow D, Börger A, Wark M, Atanassova P and Valenciano J 2013 J. Power Sources 239483

[14] Understanding the function and performance of carbonenhanced lead-acid batteries, Sandia Report 2011. Available at: http://prod.sandia.gov/techlib/access-control.cgi/2011/11826 3.pdf (accessed on 09 September 2016)

[15] Kozawa A, Oho H, Sano M, Brodd D and Brodd R $1999 \mathrm{~J}$. Power Sources $\mathbf{8 0} 12$

[16] Moseley P T, Nelson R F and Hollenkamp A F 2006 J. Power Sources 1573

[17] Banerjee A, Saha D, Row T N G and Shukla A K 2013 Bull. Mater. Sci. 36163

[18] Saravanan M, Sennu P, Ganesan M and Ambalavanan S 2012 J. Electrochem. Soc. 160 A70

[19] Pavlov D (ed) 2011 Lead-acid batteries: science and technology (Netherlands: Elsevier Science)

[20] Pavlov D and Kapkov N 1990 J. Electrochem. Soc. 13716

[21] Jung J, Zhang L and Zhang J (eds) 2015 Lead-acid battery technologies: fundamentals, materials, and applications (New York: Taylor \& Francis Group)

[22] Pavlov D and Iliev V 1981 J. Power Sources 7153

[23] Lam L T, Haigh N P, Phyland C G and Urban A J 2004 J. Power Sources 133126
[24] Fernández M, Trinidad F, Valenciano J and Sánchez A 2006 J. Power Sources 1581149

[25] Moseley P T, Garche J, Parker C D and Rand D A J (eds) 2004 Valve-regulated lead-acid batteries (Netherlands: Elsevier Science)

[26] Soria M L, Trinidad F, Lacadena J M, Sánchez A and Valenciano J 2007 J. Power Sources 16812

[27] Moseley P T 2004 J. Power Sources 12727

[28] Soria M L, Hernàndez J C, Valenciano J and Sànchez A 2005 J. Power Sources 144473

[29] Sugumaran N, Everill P, Swogger S W and Dubey D P 2015 J. Power Sources 279281

[30] Sawai K, Funato T, Watanabe M, Wada H, Nakamura K, Shiomi M et al 2006 J. Power Sources 1581084

[31] Pavlov D and Nikolov P 2012 J. Electrochem. Soc. 159 A1215

[32] McNally T and Klang J 2003 J. Power Sources 11647

[33] Ruetschi P 2004 J. Power Sources 12733

[34] Boden D, Arias J and Fleming F A 2001 J. Power Sources 95 277

[35] Dietz H, Niepraschk H, Wiesener K, Garche J and Bauer J 1993 J. Power Sources 46191

[36] Pavlov D, Petkova G and Rogachev T 2008 J. Power Sources 175586

[37] Yamaguchi Y, Shiota M, Nakayama Y, Hirai N and Hara S 2000 J. Power Sources $\mathbf{8 5} 22$

[38] Cooper A and Moseley P T 2003 J. Power Sources 113200

[39] Moseley P T, Rand D A J and Monahov B 2012 J. Power Sources 21975

[40] Moseley P T, Hutchison J L, Wright C J, Bourke M A M, Hill R I and Rainey V S 1983 J. Electrochem. Soc. 130 829

[41] Pavlov D, Rogachev T, Nikolov P and Petkova G 2009 J. Power Sources 19158

[42] Atanassova P, Pasquier A D, Oljaca M, Nikolov P, Matrakova $\mathrm{M}$ and Pavlov D 2014 International conference on lead-acid batteries, LABAT, p 5

[43] Catherino H A, Feres F F and Trinidad F 2004 J. Power Sources 129113

[44] Moseley P T 2009 J. Power Sources 191134

[45] Pavlov D, Nikolov P and Rogachev T 2010 J. Power Sources 1965155

[46] Carbon-carbon bonds Hybridization, Handout 2011. Available at: http://www.physik.fu-berlin.de/einrichtungen/ag/ag-reich/ lehre/Archiv/ss2011/docs/Gina_Peschel-Handout.pdf (accessed on 09 September 2016)

[47] Xiang J, Ding P, Zhang H, Wu X, Chen J and Yang Y 2013 J. Power Sources 241150

[48] Marom R, Ziv B, Banerjee A, Cahana B, Luski S and Aurbach D 2015 J. Power Sources 29678

[49] Banerjee A, Ziv B, Levi E, Shilina Y, Luski S and Aurbach D 2016 J. Electrochem. Soc. 163 A1518

[50] Banerjee A, Ziv B, Shilina Y, Levi E, Luski S and Aurbach D 2017 ACS Appl. Mater. Interfaces 93634

[51] Logeshkumar S and Manoharan R 2014 Electrochim. Acta 144 147

[52] Yeung K K, Zhang X, Kwok S C T, Ciucci F and Yuen M M F 2015 RSC Adv. 571314

[53] Calábek M, Micka K, Křivák P and Bača P 2006 J. Power Sources $\mathbf{1 5 8} 864$

[54] Pavlov D, Nikolov P and Rogachev T 2010 J. Power Sources 1954435 
[55] Micka K, Calábek M, Bača P, Křivák P, Lábus R and Bilko R 2009 J. Power Sources 191154

[56] Shukla A K, Banerjee A, Ravikumar M K and Jalajakshi A 2012 Electrochim. Acta 84165

[57] Jaiswal A and Chalasani S C 2015 J. Energy Storage 115

[58] Pavlov D and Nikolov P 2013 J. Power Sources 242380

[59] Kumar R, Kumari S, Mathur R B and Dhakate S R 2015 Appl. Nanosci. 553

[60] Swogger S W, Everill P, Dubey D P and Sugumaran N 2014 J. Power Sources 26155

[61] Wissler M 2006 J. Power Sources 156142

[62] Shapira R, Nessim G D, Zimrin T and Aurbach D 2013 Energy Environ. Sci. 6587

[63] Bullock K R 2010 J. Power Sources 1954513

[64] Wong B, Jiang L X, Xue H T, Liu F Y, Jia M, Li J et al 2014 J. Power Sources 270332

[65] Hariprakash B, Gaffoor S A and Shukla A K 2009 J. Power Sources 191149

[66] Liu C, Yu Z, Neff D, Zhamu A and Jang B Z 2010 Nano Lett. 104863

[67] Stoller M D, Park S, Zhu Y, An J and Ruoff R S 2008 Nano Lett. 83498

[68] Ni Z H, Wang H M, Kasim J, Fan H M, Yu T, Wu Y H et al 2007 Nano Lett. 72758

[69] Du X, Skachko I, Barker A and Andrei E Y 2008 Nat. Nanotechnol. 3491

[70] Kim H, Abdala A A and Macosko C W 2010 Macromolecules 436515

[71] Cinke M, Li J, Chen B, Cassell A, Delzeit L, Han J et al 2002 Chem. Phys. Lett. 36569

[72] Niu C, Sichel E K, Hoch R, Moy D and Tennent H 1997 Appl. Phys. Lett. 701480

[73] Eatemadi A, Daraee H, Karimkhanloo H, Kouhi M, Zarghami N, Akbarzadeh A et al 2014 Nanoscale Res. Lett. 9393

[74] Chen T and Dai L 2013 Mater. Today 16272

[75] Dai L, Dai L, Chang D W, Baek J and Lu W 2012 Small 81130
[76] Frackowiak E, Jurewicz K, Delpeux S and Béguin F $2001 \mathrm{~J}$. Power Sources 97-98 822

[77] Futaba D N, Hata K, Yamada T, Hiraoka T, Hayamizu Y, Kakudate Y et al 2006 Nat. Mater. 5987

[78] Lehman J H, Terrones M, Mansfield E, Hurst K E and Meunier V 2011 Carbon 492581

[79] Klingeler R and Sim R B (eds) 2011 Carbon nanotubes for biomedical applications (Berlin: Springer)

[80] Bachtold A, Fuhrer M S, Plyasunov S, Forero M, Anderson E H, Zettl A et al 2000 Phys. Rev. Lett. 846082

[81] Fan Q, Qin Z, Liang X, Li L, Wu W and Zhu M 2010 J. Exp. Nanosci. 5337

[82] Grossiord N, Loos J, Regev O and Koning C E 2006 Chem. Mater. 181089

[83] Li X, Wong S Y, Tjiu W C, Lyons B P, Oh S A and He C B 2008 Carbon 46818

[84] Du J, Zhao L, Zeng Y, Zhang L, Li F, Liu P and Liu C 2010 Carbon 491094

[85] Martin-Gallego M, Bernal M M, Hernandez M, Verdejo R and Lopez-Manchado M A 2013 Eur. Polym. J. 491347

[86] Chatterjee S, Nüesch F A and Chu B T T 2011 Nanotechnology 22275714

[87] Lam L T and Louey R 2006 J. Power Sources 1581140

[88] Furukawa J, Takada T, Monma D and Lam L T 2010 J. Power Sources 1951241

[89] Pavlov D 1997 J. Power Sources 64131

[90] Hong B, Yu X, Jiang L, Xue H, Liu F, Li J et al 2014 RSC Adv. 433574

[91] Wang F, Hu C, Lian J, Zhou M, Wang K, Yan J et al 2017 RSC Adv. 74174

[92] Li W, Zhou M, Li H, Wang K, Cheng S and Jiang K 2015 Energy Environ. Sci. 82916

[93] Hariprakash B, Bera P, Martha S K, Gaffoor S A, Hegde M S and Shukla A K 2001 Electrochem. Solid State Lett. 4 A23

[94] Dietz H, Dittmar L, Ohms D, Radwan M and Wiesener K 1992 J. Power Sources 40175 